\title{
CORPORATE INCOME TAX: EFFECTIVENESS IN THE CONTEXT OF PUBLIC FISCAL POLICY AND ENTREPRENEURSHIP SUPPORT
}

\author{
Tetyana Vasilyeva \\ Sumy State University, SSU, Ukraine \\ bel_editor.armg@ssu.edu.ua \\ Alina Vysochyna \\ Sumy State University | SSU, Ukraine \\ Alina Taranchenko \\ Sumy State University | SSU, Ukraine
}

\begin{abstract}
The article analyzes the approaches to the definition of the essence and quantitative assessment of the fiscal effectiveness of the income tax. According to the results of the study, it was found out that the fiscal effectiveness of the income tax can be estimated through the indicators of fiscal importance of the tax in the tax revenues of the state (consolidated) budget; tax burden of the tax (in relation to GDP); elasticity of income tax; effective tax rate and tax productivity, etc. The analysis of the dynamics of these indicators over the past few years in Ukraine has allowed us to confirm the low level of fiscal effectiveness and regulatory potential of this tax for Ukraine. One of the possible ways to improve the fiscal effectiveness of the income tax is to use indirect channels of influence, which are represented by the general state of the country's economic development, labor market efficiency, level of welfare of the population, investment attractiveness, and performance of enterprises. The empirical study of determining the most significant channels of influence on the indicators of fiscal effectiveness of the income tax has made it possible to find out: 1) growth of absolute amounts of income tax revenue can be achieved through the use of the investment channel, budget channel and labor market channel; 2) increase in the tax burden on income tax is contributed by the increase in the revenues of the Consolidated Budget, index of industrial producer prices and consumer price index, and increase of the employment rate, while the improvement of the indicators of the overall economic development of the state and investment climate leads to reduction of the tax burden; 3 ) increase in the fiscal significance of the income tax is contributed by the increase in growth rate of direct investment, level of employment and real wages. Thus, the analysis conducted allowed to identify the channels through which authorities can influence the fiscal effectiveness of the income tax.
\end{abstract}

Keywords: public fiscal policy, income tax, entrepreneurship support, fiscal effectiveness. JEL Classification: E62, H25 


\section{INTRODUCTION}

The transformation of Ukraine's tax system is aimed at synchronizing with the European tax practice and key global principles for building the tax system. The main changes are aimed at simplifying the mechanisms of accrual and payment of taxes, as well as the rejection of inefficient fiscal instruments in favor of more efficient and effective. In connection with the active discussion of the need for the transformation of the corporate income tax in Ukraine into a tax on withdrawn capital, the study of the fiscal effectiveness of the income tax both from the standpoint of the state and the business, as well as confirmation or disproof on the basis of the analysis of the feasibility of such changes, is becoming particularly relevant.

\section{LITERATURE REVIEW}

There are a large number of publications of Ukrainian and foreign scientists devoted to the study of features of taxation of income tax, as well as individual approaches to assessing its fiscal effectiveness, in particular: V.P. Khomutenko [1] investigated the general aspects of the fiscal effectiveness of the corporate income tax in Ukraine and its dynamics; T.A. Dalievska [2] and N.B. Yaroshevych [3] conducted a study of the fiscal effectiveness of the corporate profit tax in Ukraine from the point of view of the potential of this tax for the formation of revenues of the state budget; V.P. Vyshnevskyi [4] carried out an indirect analysis of the fiscal effectiveness of the income tax through the determination of its internal nature, the place and value of this tax in tax systems of different countries; K.V. Bezverkhyi [5] considered the issue of accounting and reporting on income tax in the context of economic changes, introduced a mechanism for calculating the object of taxation of corporate income tax using the data of the Report on financial results, etc. Thus, it may be noted that most research on the fiscal effectiveness of the income tax is aimed at assessing the budget-generating potential of this tax, while its acceptability and regulatory efficiency for the corporate sector remain neglected, which causes the necessity of further research in this direction.

\section{Methods}

According to the Tax Code of Ukraine [6], the income tax belongs to the national tax and is one of the sources of filling the state budget. At the same time, discussions on the fiscal effectiveness of this tax for the state and business and the prospects for its transformation into the tax on withdrawn capital have intensified recently.

The modern economic dictionary interprets the notion of "effectiveness" as a relative effect, effectiveness of a process, operation, project, which is defined as the ratio of effect, result to costs, costs, which caused and ensured its receipt [7]. That is, the effectiveness reveals the causal relationships between input resources and the end result.

At the same time, the fiscal effectiveness of the income tax is a productive indicator that characterizes various aspects of the ratio of concepts of "resource-result" both at the national level and at the level of a particular enterprise, the content of which is most fully understood through the prism of quantitative indicators of its evaluation. [8].

The generalization of scientific approaches $[9,10,11,12]$ allowed to distinguish the following indicators of quantitative assessment of the fiscal effectiveness of the income tax for the state and business:

- indicator of fiscal significance of the income tax in the state budget characterizes the budget-generating potential of the income tax; allows to quantify the "response" of 
taxpayers to realized tax decisions, that is, shows a real change in value of tax revenue from income tax;

- tax burden on income tax makes it possible to see the level of the general tax burden on income tax and reflects the mechanism of redistribution of GDP through the state budget with the help of this instrument;

- coefficient of elasticity of the income tax shows how the amount of tax revenues to the budget of Ukraine varies depending on the change in GDP. If the value of the coefficient is greater than or equal to 1 , then the tax is elastic, and therefore has a significant regulatory potential. If the coefficient is less than 1 , then the tax is inelastic and, accordingly, has an insignificant stabilizing effect;

- indicator of the effectiveness of administration of income tax characterizes the return on incurred expenses for the collection of income tax;

- coefficient of ratio of profit tax effectiveness in GDP is used as a total indicator of the effectiveness of a separate tax type;

- coefficient of irregularity of income tax revenue characterizes the systematic fluctuations in income tax revenue;

- effective tax rate characterizes the degree of use of the potential tax base by the income tax;

- coefficient of performance and effective rate are interconnected and show the compliance of the legally established tax rate with the real rate; this and the preceding figures are indicators that characterize the optimality and acceptability of the system of profitable taxation for business;

- coefficient of fiscal capacity of the tax taking into account the shadow sector - this indicator should approach 1.

The procedure for calculating the indicators of fiscal effectiveness of the income tax for the state and business is presented in Table 1.

Table 1. The system of coefficients for assessing the fiscal effectiveness of the income tax for the state and business [Error! Reference source not found., Error! Reference source not found., Error! Reference source not found., Error! Reference source not found.]

\begin{tabular}{|c|c|}
\hline Indicator & Method of calculation \\
\hline \multicolumn{2}{|l|}{ For the state } \\
\hline $\begin{array}{l}\text { Fiscal significance of the } \\
\text { income tax in the state } \\
\text { budget }\end{array}$ & $\begin{array}{l}\text { where Fs - fiscal significance of the tax in the state budget; } \\
\text { wITTR - tax revenues from the income tax to the State } \\
\text { Budget for the year; } \\
\text { SBR - revenues of the State Budget for the year. }\end{array}$ \\
\hline Tax burden on income tax & $\begin{array}{l}\quad \% \text {, } \\
\text { where } T B-\text { tax burden on income tax; } \\
\text { CITTR - tax revenues from the income tax to the State } \\
\text { Budget for the year; } \\
\text { GDP - Gross Domestic Product for the year. }\end{array}$ \\
\hline $\begin{array}{l}\text { Coefficient of elasticity of } \\
\text { the income tax }\end{array}$ & $\begin{array}{l}\mathrm{K}_{\mathrm{E}}- \\
\text { where } \mathrm{K}_{\mathrm{E}}-\text { coefficient of elasticity of the tax; } \\
\text { CITTR - basic level of tax revenues; }\end{array}$ \\
\hline
\end{tabular}




\begin{tabular}{|c|c|}
\hline & $\begin{array}{l}\triangle C I T T R \text { - increase in tax revenues; } \\
\text { GDP - basic level of GDP; } \\
\triangle C D P \text { - GDP growth. }\end{array}$ \\
\hline $\begin{array}{l}\text { Indicator of effectiveness of } \\
\text { income tax (IT) } \\
\text { administration }\end{array}$ & $\begin{array}{l}\mathrm{K} \\
\text { service } \\
\text { where } \mathrm{K}_{\text {ea }}-\text { rate of effectiveness of income tax } \\
\text { administration. }\end{array}$ \\
\hline $\begin{array}{l}\text { Coefficient of irregularity of } \\
\text { income tax revenue }\end{array}$ & $\begin{array}{ll}\mathrm{K} & \\
\mathrm{K} & \end{array}$ \\
\hline $\begin{array}{l}\text { Coefficient of the ratio of tax } \\
\text { effectiveness to the income } \\
\text { in GDP }\end{array}$ & $\begin{array}{l}\mathrm{K}_{\mathrm{E}}- \\
\text { where } K_{E}-\text { coefficient of effectiveness ratio; } \\
\text { CITTR - tax revenues from the income tax to the State } \\
\text { Budget for the year; } \\
\text { GDP - Gross Domestic Product for the year; } \\
\text { Rate - tax rate. }\end{array}$ \\
\hline \multicolumn{2}{|l|}{ For business } \\
\hline Effective tax rate & $\begin{array}{l}\mathrm{E}-\% \text {, } \\
\text { where } E_{r}-\text { effective income tax rate; } \\
\text { CITTR - tax revenues from the income tax to the State } \\
\text { Budget for the year; } \\
F R \text { - financial result before taxation for the year. }\end{array}$ \\
\hline $\begin{array}{l}\text { Performance coefficient of } \\
\text { the income tax }\end{array}$ & $\begin{array}{l}\mathrm{K} \quad \mathrm{Er} \\
\text { where } K_{p} \text { - performance coefficient of the income tax; } \\
\text { Er- effective income tax rate; } \\
\text { Rate }- \text { real income tax rate. }\end{array}$ \\
\hline Fiscal capacity coefficient & $\begin{array}{l}\text { where ACITTR - actual income tax revenues; } \\
\text { Shadow - "shadow", hidden amounts of income tax. }\end{array}$ \\
\hline
\end{tabular}

Thus, the fiscal effectiveness of the income tax should be understood as the effectiveness of the mechanism for collecting this tax both at the national level (its ability to ensure stable and significant tax revenues to the relevant budget while minimizing the cost of its administration) and for business (in terms of ensuring acceptability, transparency and simplicity of income taxation, in which taxpayers assess the tax burden as optimal and do not evade tax payments).

Existence of a wide range of quantitative indicators for assessing the fiscal effectiveness of the income tax allows to evaluate this phenomenon complexly and from different perspectives, and therefore it is expedient to analyze the trends of changes in each of them in the last few years.

\section{Results}

First of all, we will analyze the fiscal significance of the income tax in the state budget, as well as the tax burden on income tax as shown in Figure 1. 


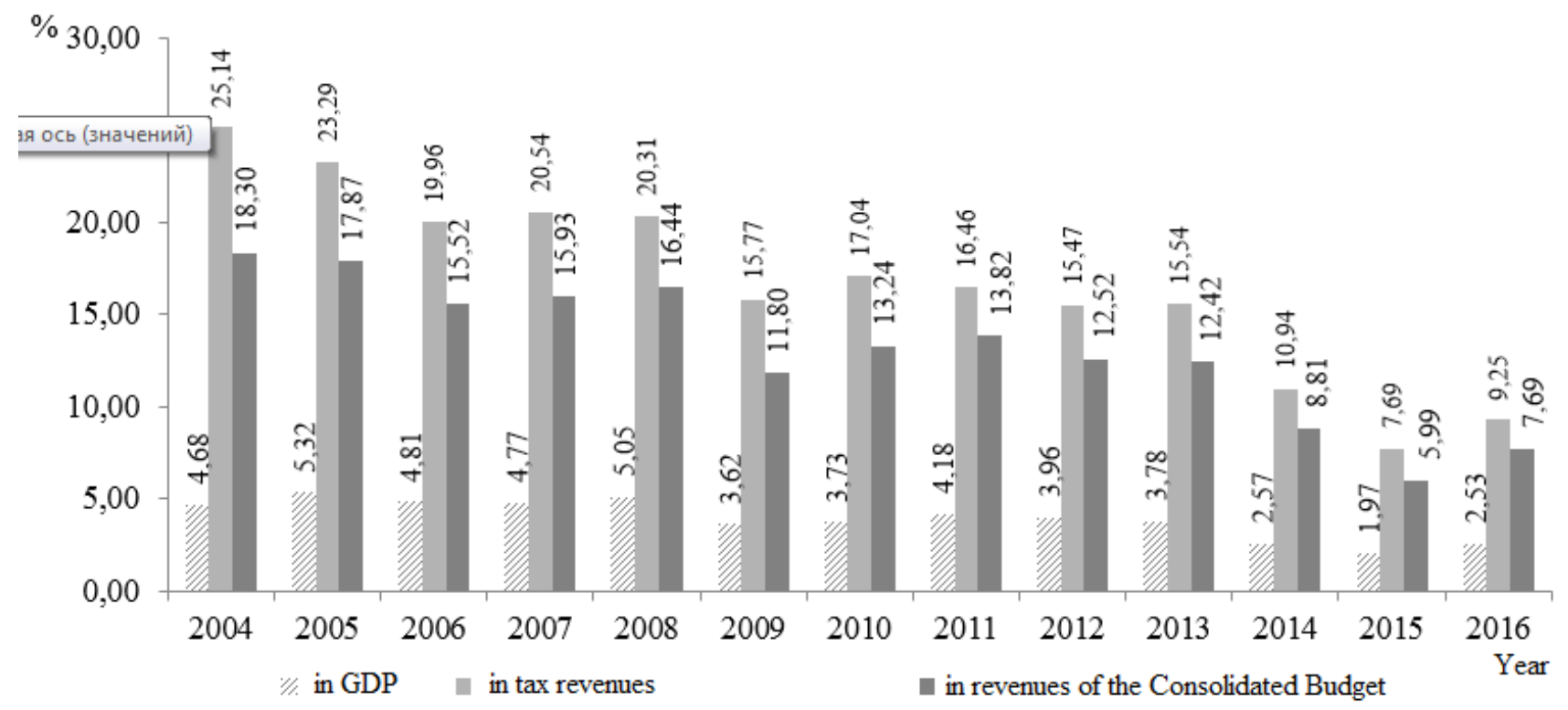

Source: based on statistical data [Error! Reference source not found., Error! Reference source not found., Error! Reference source not found.]

Figure 1. Share of corporate income tax revenues in GDP, revenues and tax revenues to the Consolidated Budget of Ukraine for 2004-2016,\%

Having analyzed the data in Figure 1, it can be argued that there is a tendency to reduce the share of income tax in these indicators in the period 2011-2015, which is due to the reduction in the tax rate on profit $(2011-23 \%, 2016-18 \%)$, calculation of the tax base (transition from tax to accounting), a reduction in the size of the tax base through a complex socio-economic and political situation in the country. Another negative factor is that some enterprises hide the amount of profit before tax, so the budget does not receive a significant amount of money from this tax. Starting from 2016, the share of profit tax increased slightly in these indicators, this can be explained by a decrease in the rate of inflation, a reduction in the number of unprofitable enterprises. However, despite the intensification of the positive trend at the end of the period under consideration, the fiscal significance of the profit tax is still extremely low, and then the importance of this tool in the context of the formation of state budget revenues and the redistribution of GDP is extremely low.

To compare fiscal significance and tax burden on income tax in Ukraine and countries of the world, we will analyze the figures in Figures 2 and 3. 


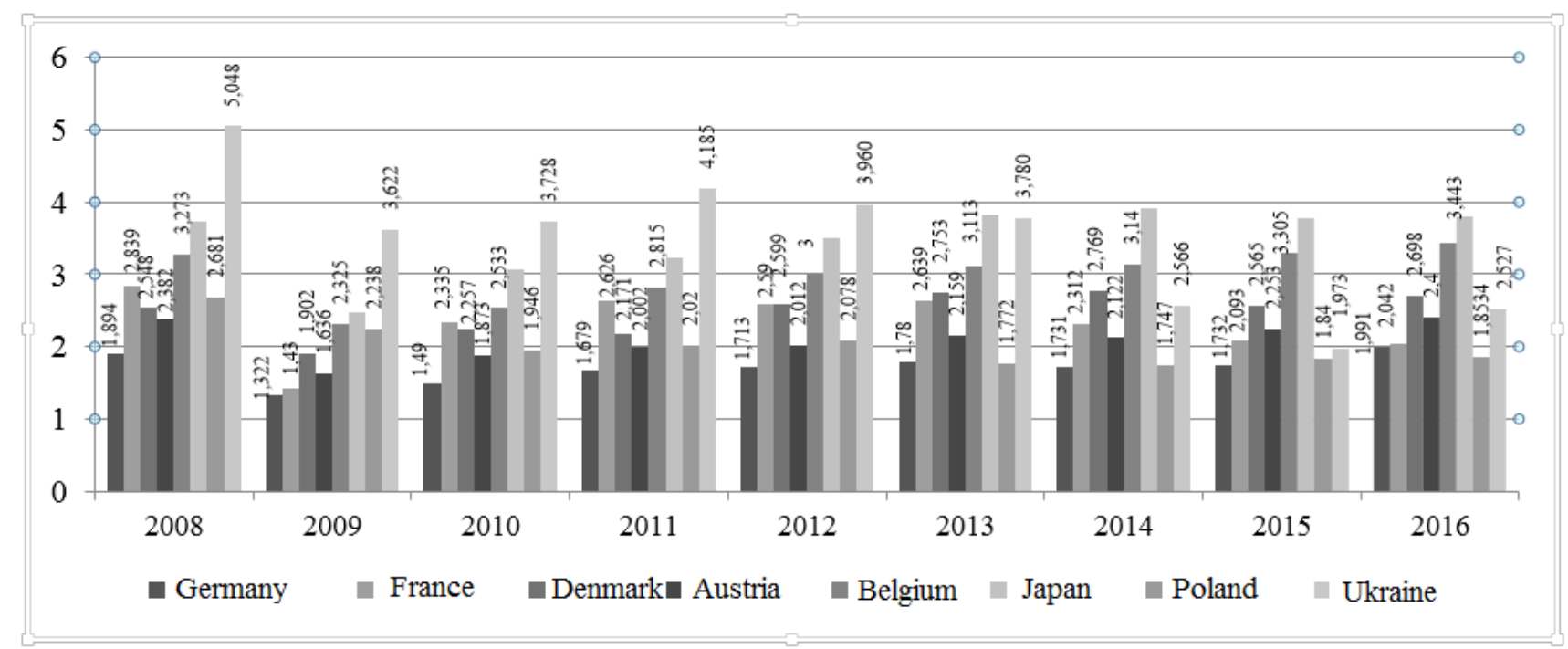

Source: based on statistical data [Error! Reference source not found.]

Figure 2. Tax revenue on income tax,\% of GDP

The data in Figure 2 show that as of 2016, Japan has the largest share of tax revenue on income tax in GDP in comparison with other countries which comprises $3.8 \%$ and the the smallest has Poland (1.9\%). Compared to other countries in terms of tax burden Ukraine has an indicator above the average. In total for the period 2008-2016, there is a tendency to reduce the share of income from income tax in the GDP of countries.

According to Figure 3, it can be noted that in 2016 Japan has the largest share of tax revenue on income tax in the total amount of tax revenue compared to other European countries (12.3\%). Ukraine also has a fairly high level of the analyzed indicator $-9.25 \%$. France has a relatively low share, this indicator is $4.51 \%$.

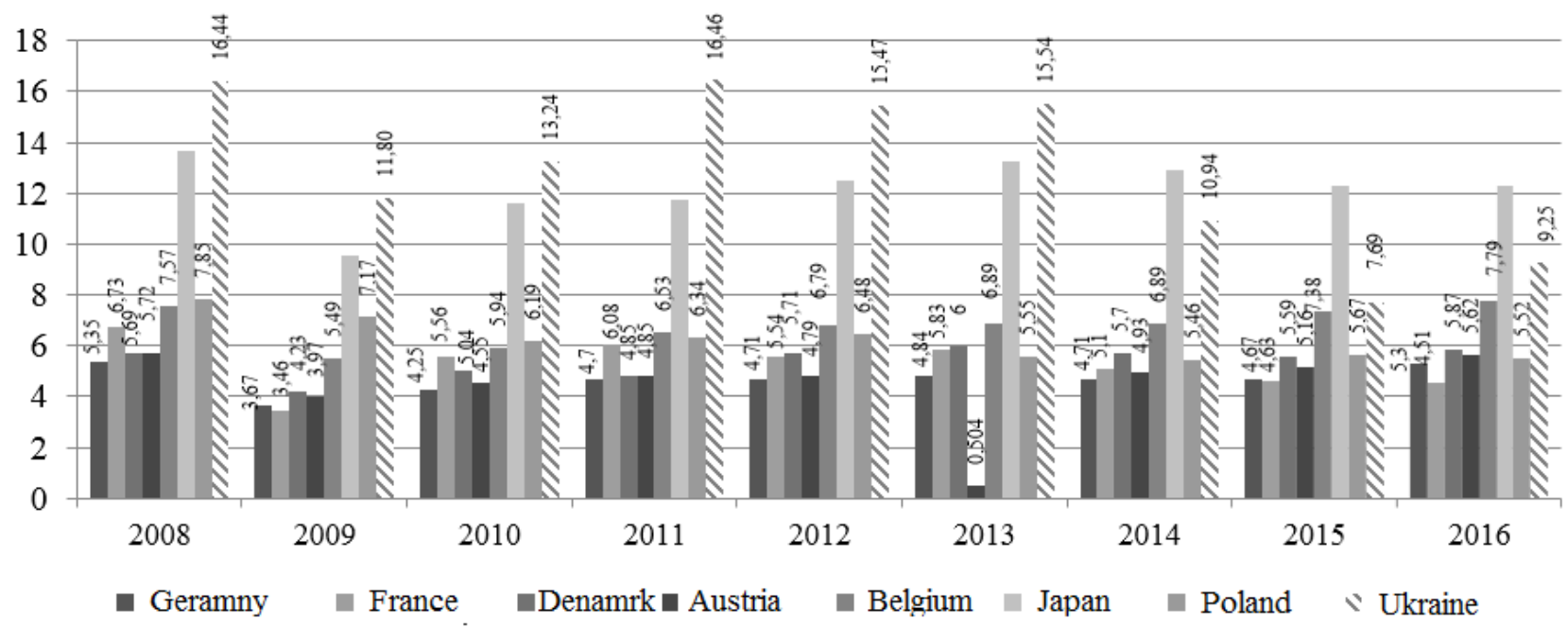

Source: based on statistical data [Error! Reference source not found.]

Figure 3. Tax revenue on income tax, $\%$ of total tax revenue

We calculate the irregularity coefficients of income tax revenues (Table 2).

Table 2. The irregularity coefficients of income from income tax 


\begin{tabular}{|c|c|c|c|c|c|}
\hline Year & Income tax, mln. UAH & $\begin{array}{l}\text { Average } \\
\text { annual } \\
\text { revenue }\end{array}$ & $\mathrm{K}_{\max }$ & $\mathrm{K}_{\min }$ & $\begin{array}{l}\text { Range of } \\
\text { variation }\end{array}$ \\
\hline 2004 & 16162 & \multirow{13}{*}{40527,69} & \multirow{13}{*}{1,49} & \multirow{13}{*}{0,40} & \multirow{13}{*}{108,7} \\
\hline 2005 & 23464 & & & & \\
\hline 2006 & 26172 & & & & \\
\hline 2007 & 34407 & & & & \\
\hline 2008 & 47857 & & & & \\
\hline 2009 & 33078 & & & & \\
\hline 2010 & 40359 & & & & \\
\hline 2011 & 55097 & & & & \\
\hline 2012 & 55793 & & & & \\
\hline 2013 & 54994 & & & & \\
\hline 2014 & 40201 & & & & \\
\hline 2015 & 39053 & & & & \\
\hline 2016 & 60223 & & & & \\
\hline
\end{tabular}

Source: compiled by authors based on statistical data [Error! Reference source not found.]

The irregularity coefficients and the range of variation indicate that there are insignificant fluctuations in the income tax receipts during the analyzed period, since the difference between the maximum $(1,183)$ and the minimum $(0,767)$ income factors is small.

From the position of assessing the fiscal efficiency of the corporate income tax, it is important to calculate the effective rate of income tax (Table 3).

Table 3. Effective tax rate on profit and tax performance in Ukraine for 2009-2016

\begin{tabular}{|c|c|c|c|c|c|c|c|c|}
\hline \multirow[t]{2}{*}{ Indicator } & \multicolumn{8}{|l|}{ Year } \\
\hline & 2009 & 2010 & 2011 & 2012 & 2013 & 2014 & 2015 & 2016 \\
\hline $\begin{array}{l}\text { Financial result } \\
\text { before taxation, } \\
\text { mln. UAH. }\end{array}$ & $\begin{array}{l}14370 \\
6,6\end{array}$ & $\begin{array}{l}21200 \\
8,6\end{array}$ & $\begin{array}{l}272726, \\
2\end{array}$ & $\begin{array}{l}277938, \\
5\end{array}$ & $\begin{array}{l}234513, \\
7\end{array}$ & $\begin{array}{l}334517, \\
3\end{array}$ & $\begin{array}{l}475321 \\
2\end{array}$ & $\begin{array}{l}523759, \\
4\end{array}$ \\
\hline $\begin{array}{l}\text { Tax revenue } \\
\text { from income } \\
\text { tax, mln. UAH }\end{array}$ & 33078 & 40359 & 55097 & 55793 & 54994 & 40201 & 39053 & 60223 \\
\hline $\begin{array}{ll}\text { Effective } & \text { tax } \\
\text { rate, } \% & \end{array}$ & 23,02 & 19,04 & 20,20 & 20,07 & 23,45 & 12,02 & 8,22 & 11,50 \\
\hline $\begin{array}{l}\text { The efficiency of } \\
\text { the tax,\% }\end{array}$ & 92,07 & 76,15 & 87,83 & 95,57 & 123,42 & 66,78 & 45,67 & 63,89 \\
\hline
\end{tabular}

Source: based on statistical data [Error! Reference source not found., Error! Reference source not found.]

The performed calculations allow to draw a conclusion about the existence of discrepancies between the actual and effective rate of corporate income tax in Ukraine. In particular, almost during the entire study period, the effective rate is lower than the actual rate. From the position of the corporate sector, this situation is acceptable, because it indicates the withdrawal of part of the taxable profit from the base, but in the perspective of the state this practice indicates a shortage of tax revenue. Consequently, we can conclude that the fiscal effectiveness of the profit tax from the point of view of the state is 
very low, which necessitates its transformation. The smallest size of the rate corresponds to the lowest efficiency of the profit tax.

Thus, the analysis shows the need to reform the system of corporate profit taxation, which is due to the existence of problems both within the framework of the tax mechanism itself and its low fiscal efficiency for the state budget (empirically confirmed by calculations in the framework of this study), as well as low regulatory capacity in contrast to the developed countries of the world. Solving these problems will increase the fiscal efficiency of the profit tax, reduce the process of shadowing business and the withdrawal of capital, improve the investment climate in the country, that is, it will fully realize not only the fiscal but also the regulatory function of the profit tax.

In the context of improving the level of the fiscal efficiency of the profit tax, it is necessary to identify the factors affecting it. The analysis of the literature sources allowed to generalize the factors of influence on fiscal efficiency, as well as to offer indicators of their quantification (Table 4).

Table 4. Factors influencing the fiscal efficiency of the profit tax and quantitative indicators of their quantification

\begin{tabular}{|l|l|l|l|}
\hline № & Factor & Indicator & Source of receipt \\
\hline 1 & $\begin{array}{l}\text { General parameters of } \\
\text { economic development of } \\
\text { the country }\end{array}$ & $\begin{array}{l}\text { - The rate of GDP growth. } \\
\text { Change in the GDP } \\
\text { deflator. }\end{array}$ & $\begin{array}{l}\text { Official site of the State } \\
\text { Statistics Service }\end{array}$ \\
\hline 2 & Standards of living & $\begin{array}{l}\text { - Consumer price index. } \\
- \text { Rate of growth / decrease } \\
\text { in real wages. }\end{array}$ & $\begin{array}{l}\text { Official site of the State } \\
\text { Statistics Service }\end{array}$ \\
\hline 3 & $\begin{array}{l}\text { The state of the labor } \\
\text { market }\end{array}$ & $\begin{array}{l}\text { - Employment level of the } \\
\text { population. } \\
- \text { Unemployment rate. }\end{array}$ & $\begin{array}{l}\text { Official site of the State } \\
\text { Statistics Service }\end{array}$ \\
\hline 4 & $\begin{array}{l}\text { Investment climate } \\
\text { The growth rate of direct } \\
\text { investment from the } \\
\text { countries of the world. }\end{array}$ & $\begin{array}{l}\text { Official site of the State } \\
\text { Statistics Service }\end{array}$ \\
\hline 5 & $\begin{array}{l}\text { Efficiency of large and } \\
\text { medium-sized enterprises }\end{array}$ & $\begin{array}{l}\text { The level of profitability } \\
\text { (loss) of large and medium- } \\
\text { sized enterprises. } \\
\text { - Producer price indices of } \\
\text { industrial products. }\end{array}$ & $\begin{array}{l}\text { Official site of the State } \\
\text { Statistics Service }\end{array}$ \\
\hline
\end{tabular}

Source: based on statistical data [Error! Reference source not found., Error! Reference source not found., Error! Reference source not found., Error! Reference source not found.]

Thus, the generalization of the factors that can influence the fiscal efficiency of the profit tax, as well as the identification of indicators that allow quantifying the impact of these factors, is the basis for conducting empirical analysis to define the most relevant factors of the fiscal effeciency of the profit tax in Ukraine, which in turn, can become the basis for making more effective management decisions within the framework of the state tax policy.

To develop recommendations on the most effective channels of indirect influence on the fiscal efficiency of the profit tax, an appropriate scientific and methodical approach is proposed, which provides for the sequential implementation of several stages.

The first stage of this approach is the formation of an array of statistical data of the main factorial and performance indicators, which serve as the information base for the 
study. As quantitative variables, quantitative measures of the factors influencing the fiscal efficiency of the profit tax were presented in Table 4. The block of effective variables is represented by separate indicators of the characteristic of fiscal efficiency, the list of which is presented in Table 1. The time range of the study covers the period 2005-2016. The tool for determining the nature and direction of the influence of factors on the fiscal effectiveness of the profit tax is multifactorial regression modeling, performed using the software product Stata 12.

The second step of the approach is directly the implementation of regression modeling and characterization of the results obtained in the context of a separate performance indicator. It is worth noting that the set of independent variable models varies, which is due to the search for the most significant variant, based on the value of the determination coefficient (in different models the value of the indicator varies from 0.93 to 0.99).

Let's turn to the direct description of the results of the study. The calculation of the influence of factors on the amount of income tax is shown in Table 5.

Table 5. Calculation of the influence of factors on the amount of income tax

\begin{tabular}{|l|l|l|}
\hline Income tax, UAH million & Coefficient & $\mathrm{P}>|\mathrm{t}|$ \\
\hline GDP growth rate,\% & -398.2344 & 0,014 \\
\hline Consolidated Budget Revenues, mln. & 0.0503058 & 0,001 \\
\hline $\begin{array}{l}\text { Industrial producer price indices,\% (before } \\
\text { December of the previous year) }\end{array}$ & 803.2992 & 0,003 \\
\hline Rate of growth of direct investments,\% & 99.53775 & 0,045 \\
\hline $\begin{array}{l}\text { Employment rate,\% of the total population } \\
\text { Real wage growth rate,\% (before the } \\
\text { previous year) }\end{array}$ & 23324.67 & 0,001 \\
\hline Constant & 278.3573 & 0,014 \\
\hline
\end{tabular}

Therefore, the values given in the column "factor" indicating the impact, while the indicator $" \mathrm{P}\rangle|\mathrm{t}|$ » indicates the statistical significance of the factors (the Figure should not be created than 0.1 , which corresponds to $90 \%$ confidence interval). Thus, according to the results of regression modeling, it can be noted that all parameters of the model are statistical significant on the confidence interval of $95 \%$, the determination coefficient of the model is 0.99895 . The factors that positive affect the volume of income tax revenue include the growth of the Consolidated Budget revenue of Ukraine (an increase in the factor of 1 million UAH is accompanied by an increase in the amount of income from income tax by UAH 0.0503 million); an increase in the index of industrial producer prices by $1 \%$ is accompanied by an increase in income from income tax by UAH 803.3 million; an increase in the rate of growth of direct investments by $1 \%$ is accompanied by an increase in income from income tax by UAH 99.54 million; an increase in the employment rate of $1 \%$ is accompanied by an increase in the amount of income from income tax by UAH 23324.67 million; an increase in real wages by $1 \%$ is accompanied by an increase in income from income tax by UAH 278.36 million.

Negative to the amount of income tax revenue is influenced by the growth rate of GDP growth: an increase in the factor of $1 \%$ is accompanied by a reduction in the amount of income from income tax by 398.23 million $\mathrm{UAH}$.

Thus, in the context of an increase in the absolute volume of income tax revenue, it is possible to use channels of the labor market, investment attractiveness and living 
standards of the population, while the increase in the GDP growth rate does not have a direct impact on the resultant indicator.

The calculation of the influence of factors on the level of tax burden on income tax is given in Table 6.

Table 6. Calculation of the influence of factors on the level of tax burden

\begin{tabular}{|l|l|l|}
\hline Level of tax burden & Coefficient & $\mathrm{P}>|\mathrm{t}|$ \\
\hline Change in GDP deflator,\% & -0.2812704 & 0,011 \\
\hline GDP growth rate,\% & -0.3820143 & 0,011 \\
\hline Consolidated Budget Revenues, mln. & $6.47 \mathrm{e}-06$ & 0,014 \\
\hline $\begin{array}{l}\text { Industrial producer price indices,\% (before } \\
\text { December of the previous year) }\end{array}$ & 0.393798 & 0,011 \\
\hline Consumer Price Index,\% & 0.3918592 & 0,013 \\
\hline $\begin{array}{l}\text { Direct investments (share capital) from the } \\
\text { countries of the world in the economy of } \\
\text { Ukraine, mln. USA }\end{array}$ & -0.0006064 & 0,010 \\
\hline $\begin{array}{l}\text { Employment rate,\% of the total population } \\
\text { Constant }\end{array}$ & 11.31181 & 0,010 \\
\hline
\end{tabular}

According to Table 6 it can be noted that all factor variables are statistically significant at confidence interval of $99 \%$ and $95 \%$; The model's determination coefficient is 0.9994. Consequently, the factors that determine the growth of the tax burden on income tax include the growth of consolidated budget revenue, an increase in the index of industrial producer prices and the consumer price index, and an increase in the employment rate of the population. Thus, it can be conclude that the inflationary burden and the orientation towards the budget-forming role of the corporate income tax leads to a deterioration of business conditions due to the growth of the tax burden that should be taken into account in the process of counter-cyclical tax policy.

At the same time, the reduction of the tax burden leads to an improvement in the indicators of the overall economic development of the state and the investment climate.

The calculation of the influence of factors on the fiscal significance of the income tax (the share of income tax revenue in the total amount of tax revenues) is presented in Table 7.

Table 7. Calculation of the influence of factors on the share of income from income tax in the total amount of tax revenues

\begin{tabular}{|l|l|l|}
\hline $\begin{array}{l}\text { Specific weight of income tax revenue in the } \\
\text { total amount of tax revenues }\end{array}$ & Coefficient & $\mathrm{P}>|\mathrm{t}|$ \\
\hline Consolidated Budget Revenues, mln. & -0.0000109 & 0,010 \\
\hline Rate of growth of direct investments,\% & 0.0407478 & 0,041 \\
\hline Employment rate,\% of the total population & 3.408606 & 0,035 \\
\hline $\begin{array}{l}\text { Growth rate / decrease in real wages,\% } \\
\text { (before the previous year) }\end{array}$ & 0.0559496 & 0,073 \\
\hline Constant & -234.4638 & 0,039 \\
\hline
\end{tabular}


All the factor model variables presented in Table 7 are statistically significant at one of the confidence intervals of $99 \%, 95 \%$ and $90 \%$; Determination coefficient of the model is 0.9960. Thus, it should be noted that the growth of the rate of growth of direct investments, the level of employment of the population and real wages, that is, activation of the policy in the area of improving the investment climate in Ukraine, increasing the welfare of the population and the state of the labor market, can be obtained in the sphere of the bonus also in the sphere of increase of the fiscal significance of the income tax. tax policy. Instead, the growth of the total revenues of the Consolidated Budget of Ukraine leads to a reduction in the fiscal significance of the income tax, that is, the fiscal potential of this tax is eroding at the expense of other taxes, the impact of which on the formation of budget revenues is more significant.

The calculation of the influence of factors on the coefficient of elasticity of the income tax is shown in Table 8.

Table 8. Calculation of the influence of factors on the coefficient of elasticity of the income tax

\begin{tabular}{|l|l|l|}
\hline Coefficient of elasticity & Coefficient & $\mathrm{P}>|\mathrm{t}|$ \\
\hline $\begin{array}{l}\text { Industrial producer price indices,\% (before } \\
\text { December of the previous year) }\end{array}$ & 0.2505301 & 0,009 \\
\hline $\begin{array}{l}\text { Direct investments (share capital) from the } \\
\text { countries of the world in the economy of } \\
\text { Ukraine, mln. USA }\end{array}$ & -0.000595 & 0,002 \\
\hline Employment rate,\% of the total population & 6.503385 & 0,023 \\
\hline $\begin{array}{l}\text { Growth rate / decrease in real wages,\% } \\
\text { (before the previous year) }\end{array}$ & -.2801933 & 0,051 \\
\hline Constant & -423.2944 & 0,051 \\
\hline
\end{tabular}

All variables of the model presented in Table 8 , are statistically significant at confidence intervals of $95 \%$ and $99 \%$; the determination coefficient is 0.9346 . It should be noted that the coefficient of elasticity of the income tax reflects the dependence of changes in tax revenues compared to the growth rate of GDP, that is, for the state more acceptable will be high elasticity of income tax, because the minimum economic growth will be accompanied by an increase in tax revenues accumulated in the budget, while for business. Conversely, the opportunity to create value added without excessive tax burden will be more acceptable. Consequently, an increase in the rate of profitability elasticity will be supported by an increase in the level of employment and an index of industrial output prices, while an increase in direct investment and a rise in real wages is accompanied by a reduction in the elasticity factor. The obtained results can be used in the process of countercyclical regulation, because depending on the stage of the economic cycle, it is more advantageous for state authorities to have some or other value of the coefficient of elasticity, so at the growth stage it will positively influence the filling of the state budget with high elasticity, while at the recession stage, the inelasticity of the tax on profit can help minimize the decline in the base of the formation of revenues of the state budget.

Thus, the analysis conducted allowed to identify the channels through which authorities can influence the fiscal efficiency of the income tax.

\section{Conclusions}


The mechanism of taxation of corporate profits in Ukraine has undergone several stages of evolution, during which there was a transformation of the base, rates of taxation, the mechanism of its calculation, but all these measures did not allow to greatly improve its fiscal significance, and the regulatory potential of the tax is practically absent.

In practice, several approaches have been developed to assess the fiscal efficiency of taxes, the most common of which is the calculation of the share of tax revenues in the structure of consolidated budget revenues, tax burden, effective tax rates, etc. The analysis of the calculated values of the reduced indicators on income tax has shown the low level of fiscal efficiency and regulatory potential of this tax from the state position, as well as the existence of problems with corporate profit tax (lack of transparency and confusion in the definition of the object of taxation, wide opportunities for applying tax evasion schemes from tax, etc.).

The fiscal efficiency of income taxation can also be improved through indirect influence using regulatory tools of the labor market channels, investment climate, improving the welfare of the population, etc., the combination of which will allow to influence the desired direction for a specific indicator of fiscal efficiency (absolute tax revenues, its fiscal significance or elasticity, as well as tax burden). These conclusions are confirmed by the corresponding economic-mathematical calculations.

\section{References}

1. Khomutenko V. P. (2017). Fiskalna efektyvnist podatku na prybutok pidpryiemstv v Ukraini. [The fiscal effectiveness of the corporate income tax in Ukraine], Economy and the state, 2, 61-65.

2. Dalievska T. A. (2015). Podatok na prybutok pidpryiemstv yak instrument napovnennia biudzhetu. [Corporate income tax as a tool for filling the budget], Global and national problems of the economy, 5, 363-366.

3. laroshevych N. B. Podatok na prybutok u dokhodakh derzhavnoho biudzhetu Ukrainy: problemy ta perspektyvy [Tax on income in the revenues of the state budget of Ukraine: problems and prospects]. Available at: http://www.nbuv.gov.ua/portal/chem_biol/ nvnltu/21_7/288_Jar.pdf.

4. Vyshnevskyi V.P. Nalohooblozhenye: teoryy, problemy, reshenyia [Taxation: theories, problems, solutions], Donetsk: DonNTU, YEP NAN Ukrainy, 2006, 504.

5. Bezverkhyi K. (2015). Oblik i zvitnist rozrakhunkiv za podatkom na prybutok $v$ umovakh zakonodavchykh zmin. [Accounting and reporting of payments for income tax in the conditions of legislative changes], Accounting and auditing, 4, 34-43.

6. The Tax Code of Ukraine dated 02.12.2010 No. 2755-VI. Available at: http://zakon5.rada.gov.ua/laws/show/2755-17.

7. Modern economic dictionary: Available at: http://www.ebk.net.ua/Book/Ses/index.htm

8. Paderin I.D. (2003). Naukovi i praktychni aspekty pidvyshchennia ekonomichnoi efektyvnosti suchasnoho pidpryiemstva [Scientific and practical aspects of improving the economic efficiency of a modern enterprise], Visnyk akademii ekonomichnykh nauk Ukrainy, 1, 89-95.

9. Ozerchuk O. V. (2014). Fiskalna efektyvnist nepriamykh podatkiv [Fiscal efficiency of indirect taxes], Naukovi pratsi NDFI. 2 (67), 59-70.

10. Piskova Zh. V. (2016). Formuvannia systemy pokaznykiv fiskalnoi efektyvnosti podatkiv: teoriia i praktyka [Formation of the system of indicators of fiscal effectiveness of taxes: 
theory and practice], Naukovyi visnyk Mukachivskoho derzhavnoho universytetu. Ser. : Ekonomika, 2, 174-180.

11. Rymar O. H. (2011). Fiskalna efektyvnist podatkovoi systemy v konteksti antykryzovoho rehuliuvannia. [Fiscal effectiveness of the tax system in the context of anti-crisis regulation], Actual problems of the economy, 4 (118), 224-227.

12. Pyslytsia A. V. (2008). Fiskalna efektyvnist aktsyziv: systema pokaznykiv, faktory vplyvu. [Fiscal effectiveness of excise duties: a system of indicators, factors of influence], Actual problems of the region's economy development, 4, 101-111.

13. The State Fiscal Service of Ukraine. Receipt of taxes and fees. Available at: http://sfs.gov.ua/diyalnist-/pokazniki-roboti/nadhodjennya-podatkiv-i-zborivobovyaz/nadhodjennya-podatkiv-i-zboriv/

14. Official website of the National Bank of Ukraine. Available at: https://bank.gov.ua/control/uk/index

15. Official website of the State Treasury Service of Ukraine. Available at: http://www.treasury.gov.ua/main/uk/index

16. Budgetary monitoring: Analyzing the budget for 2011-2016. Available at: http://www.ibser.org.ua/publications/monitoring categories/ richnyy

17. Official website of the State Statistics Service of Ukraine. Available at: http://www.ukrstat.gov.ua/

18. Official website of the Organization for Economic Cooperation and Development. Available at: http://www.oecd.org/tax.

This article is developed under the realization of project "Modeling and forecasting of socio-economic-political reforms roadmap in Ukraine in order to come up to sustainable economic development" that is financed by the Ministry of Education and Science of Ukraine. 